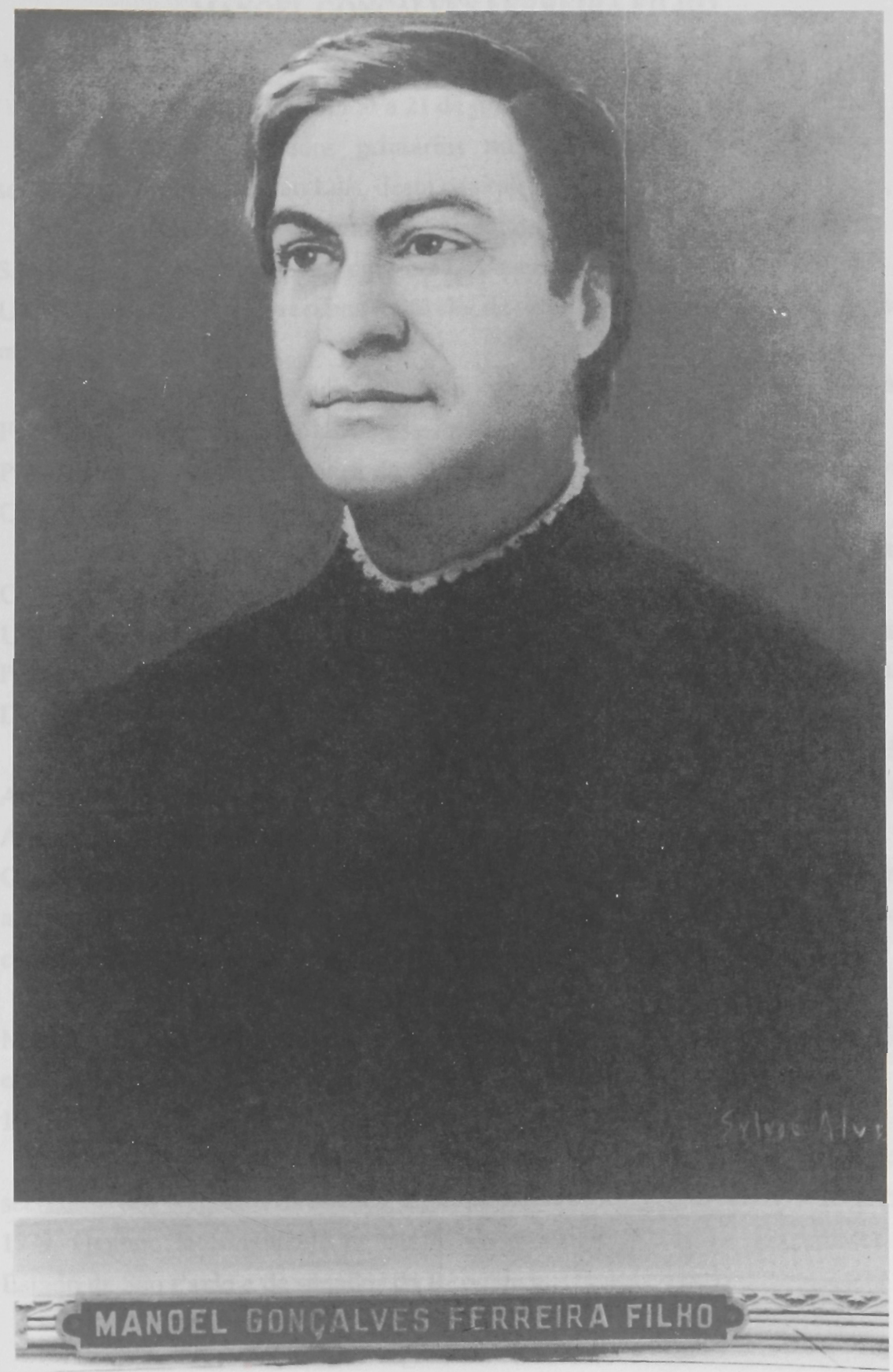





\section{MANOEL GONÇALVES FERREIRA FILHO}

(1973-1974)

Nasceu nesta capital a 21 de junho de 1934.

Fez os estudos primários no Externato Assis Pacheco e os secundários no Colégio São Luís, desta capital.

Em 1953 ingressou na Faculdade de Direito da Universidade de São Paulo, bacharelando-se em 1957. Fazendo o curso de doutorado na Universidade de Paris, recebeu o título de doutor em maio de 1960 com a menção "très bien".

Em 1965 conquista a livre-docência de Direito Constitucional nesta Faculdade, vindo ainda a lecionar esta matéria na Faculdade de Direito da Pontifícia Universidade Católica de São Paulo, além da cadeira de Introdução à Ciência do Direito, de 1960 a 1968.

$\mathrm{Na}$ Faculdade de Filosofia, Ciências e Letras da Universidade Católica, coordenou o curso de Ciências Sociais e, na mesma Faculdade da Universidade Católica de Campinas lecionou História das Idéias Políticas e Política, de 1963 a 1966. Lecionou, ainda, na Faculdade de Direito de São Paulo, Direito Internacional Privado.

Exerce a advocacia desde 1960, integrando a Ordem dos Advogados do Brasil, a Associação dos Advogados de São Paulo e o Instituto dos Advogados. Participou das comissões encarregadas de elaborar anteprojetos da Constituição do Estado em 1967 e do Código do Estado em 1969. Nesse mesmo ano, concorreu à titularidade de Direito Constitucional nesta Faculdade, classificando-se em primeiro lugar. Foi diretor da Faculdade, de 1973 a 1974.

$\mathrm{Na}$ esfera político-administrativa, foi chefe de gabinete do Ministério da Justiça em 1969 e 1970, secretário geral do mesmo órgão em 1970 e 1971, secretário do Conselho de Defesa dos Direitos da Pessoa Humana, de 1969 a 1971.

A nível estadual, foi secretário dos Negócios da Administração e secretário dos Negócios da Justiça, além de vice-governador do Estado de 1975 a 1979. Ocupou interinamente os cargos de ministro da Justiça, governador do Estado de São Paulo e de senador da República. 
Proferiu diversas conferências no exterior e no Brasil e possui vários artigos publicados em jornais e revistas especializadas. Atualmente, além da atividade docente, é membro do Conselho Federal de Educação, do Conselho de Orientação Jurídica da Federação e do Centro das Indústrias do Estado de São Paulo e chefe do Departamento de Direito do Estado desta Faculdade.

\section{Obras Publicadas}

Le statut constitutionnel des partis politiques au Brésil, en Italie, en Allemagne et en France. Paris, 1960.

O estado de sítio. São Paulo, 1964.

Os partidos políticos nas Constituiçōes democráticas. Belo Horizonte, 1966.

Curso de direito constitucional. São Paulo : Saraiva, 1967.

Do processo legislativo. São Paulo : Saraiva, 1968.

A democracia possível. São Paulo : Saraiva, 1972.

Comentários à Constituição brasileira. São Paulo, 1972.

O Poder Constituinte. São Paulo : José Bushatski, 1974.

Sete vezes democracia. São Paulo : Convívio, 1977.

Liberdades públicas, em colaboração com Ada Pellegrini Grinover e Anna

Cândida da Cunha Ferraz. São Paulo : Saraiva, 1978.

A reconstrução da democracia. São Paulo : Saraiva, 1979.

O anteprojeto dos notáveis. São Paulo : Saraiva, 1987.

Idéias para a nova Constituição brasileira. São Paulo : Saraiva, 1987.

Estado de Direito e Constituição. São Paulo : Saraiva, 1988.

Comentários à Constituição brasileira de 1988. São Paulo : Saraiva, 1990.

Direito constitucional econômico. São Paulo : Saraiva, 1990.

La nouvelle République brésilienne. Paris : Econômica, 1991. 